Part of Journal of Research of the National Bureau of Standards, Volume 30, February 1943

\title{
THERMAL EXPANSION OF TITANIUM
}

\section{By Peter Hidnert}

ABSTRACT

This paper gives data on the linear thermal expansion of titanium ( 97.2 percent) at various temperatures between $-190^{\circ}$ and $+700^{\circ} \mathrm{C}$. The coefficient of expansion of titanium increases from about $5 \times 10^{-6} /{ }^{\circ} \mathrm{C}$ at $-150^{\circ} \mathrm{C}$ to about $12 \times 10^{-6} /^{\circ}$ $\mathrm{C}$ at $650^{\circ} \mathrm{C}$. The data on thermal expansion do not indicate the existence of polymorphic transformations of titanium between $-190^{\circ}$ and $+700^{\circ} \mathrm{C}$.

CONTENTS

I. Introduction _ _

II. Material investigated

III. Apparatus _...

IV. Results _.

\section{INTRODUCTION}

Very little information is available on the thermal expansion of titanium. The Metals Handbook of the American Society for Metals (1939 edition) gives $7.14 \times 10^{-6} /{ }^{\circ} \mathrm{C}$ for the coefficient of linear thermal expansion of titanium at room temperature. The author has been informed that this value was obtained ${ }^{1}$ on a fragment of titanium of "about 98 to 99 percent purity" with the Fizeau-Pulfrich interferometer method between $24^{\circ}$ and $153^{\circ} \mathrm{C}$. The linear thermalexpansion curve of titanium was found to be practically a straight line for this range of temperature.

In order to obtain data on the linear thermal expansion of titanium over a wider temperature range, an investigation was undertaken at the National Bureau of Standards, and the results at various temperatures between $-190^{\circ}$ and $+700^{\circ} \mathrm{C}$ are given in this paper.

\section{MATERIAL INVESTIGATED}

A plate of cast titanium about 6 inches in diameter and $\frac{3}{8}$ inch in thickness was obtained from the Titanium Alloy Manufacturing Co. A number of samples were prepared from this casting for chemical analysis and for determinations of the density and linear thermal expansion. An Alundum abrasive disk, 60 grit-K4L, 8 inches in diameter and $1 / 8$ inch in thickness, was found to be satisfactory for cutting the samples from the plate of titanium. The surfaces of the samples were finished by wet grinding with an Alundum wheel.

\footnotetext{
1 By the Titanium Alloy Manufacturing Co., Niagara Falls, N. Y.
} 
The chemical composition ${ }^{2}$ of a sample of the cast titanium was found to be as follows: carbon 0.22 , manganese 0.01 , silicon 1.05 , vanadium 0.17 , iron 1.11 , columbium less than 0.2 , copper less than 0.01, titanium (by difference) 97.2 percent. Attempts to obtain a rod or plate of titanium having a purity of 99 percent or higher were unsuccessful.

The densities ${ }^{3}$ of two samples were found to be $4.542 \mathrm{~g} / \mathrm{cm}^{3}$ and $4.546 \mathrm{~g} / \mathrm{cm}^{3}$ at $25^{\circ} \mathrm{C}$.

Two samples (1641A and 1641B) were used for the determinations of linear thermal expansion. The length of each sample was $15 \mathrm{~cm}$. The cross sections of samples $1641 \mathrm{~A}$ and $1641 \mathrm{~B}$ were 20 by $10 \mathrm{~mm}$ and 14 by $9 \mathrm{~mm}$, respectively.

\section{APPARATUS}

The fused-quartz-tube expansion apparatus described by Hidnert and Sweeney ${ }^{4}$ was used for determinations of the linear thermal expansion of sample $1641 \mathrm{~B}$ over the range $-190^{\circ}$ to $+20^{\circ} \mathrm{C}$. Liquid air, solid carbon dioxide in a mixture of equal parts of carbon tetrachloride and chloroform, and ice and water were used for the lowtemperature baths at about $-190^{\circ},-78^{\circ}$, and $0^{\circ} \mathrm{C}$, respectively.

Determinations of the linear thermal expansion of sample $1641 \mathrm{~A}$ were made at various temperatures between $20^{\circ}$ and $700^{\circ} \mathrm{C}$ with the precision micrometric thermal-expansion apparatus described by Souder and Hidnert. ${ }^{5}$ Figure 5 of their publication indicates the method used in mounting the sample in the furnace. A platinumosmium (about 6 $\frac{1}{2}$ percent of osmium) observation wire 0.002 inch in diameter was placed in a sharp $V$ groove cut near each end of the sample.

\section{RESULTS}

Figures 1 and 2 show the observations on the linear thermal expansion of sample $1641 \mathrm{~B}$ at low temperatures $\left(-190^{\circ}\right.$ to $\left.+20^{\circ} \mathrm{C}\right)$ and of sample $1641 \mathrm{~A}$ at elevated temperatures $\left(20^{\circ}\right.$ to $\left.700^{\circ} \mathrm{C}\right)$. The contraction and expansion curves of sample $1641 \mathrm{~B}$ at low temperatures were found to coincide. However, the expansion and contraction curves of sample $1641 \mathrm{~A}$ at elevated temperatures did not coincide. In the first test of the latter sample to $500^{\circ} \mathrm{C}$, the observations on cooling were slightly below the expansion curve. In the next test to $700^{\circ} \mathrm{C}$, the contraction curve was appreciably above the expansion curve. The heat treatment of the sample incident to the heating and cooling cycle of this test stabilized the sample to such an extent that on a repetition of the test over the same temperature range $\left(20^{\circ}\right.$ to $\left.700^{\circ} \mathrm{C}\right)$ the observations on cooling were close to the expansion curve.

${ }^{2} \mathrm{D}$ stermined by J. L. Hague, of the National Bureau of Standards.

3 Determined by Mary G. Blair, of the National Bureau of Standards.

$4 \mathrm{P}$. Hidnert and W. T. Sweeney, Thermal expansion of magnesium and some of its alloys, BS J. Research 1, 771 (1928) R P29.

${ }_{5} \mathrm{~W}$. Souder and P. Hidnert, Measurements on the thermal jexpansion of fused silica, BS Sci. Pap. 21, 1 (1926-27) S524. 
The coefficients of expansion of titanium which were derived from the curves in figures 1 and 2 are given in table 1 .

TABLE 1.-Coefficients of linear expansion of titanium

\begin{tabular}{|c|c|c|c|c|c|c|c|c|c|c|c|c|}
\hline \multirow[b]{2}{*}{ Sample } & \multirow[b]{2}{*}{ Test } & \multicolumn{11}{|c|}{ Average coefficients of expansion and contraction per degree centigrade } \\
\hline & & $\begin{array}{r}-190^{\circ} \\
\text { to } \\
-80^{\circ} \mathrm{C}\end{array}$ & $\begin{array}{c}-80^{\circ} \\
\text { to } \\
+20^{\circ} \mathrm{C}\end{array}$ & $\begin{array}{r}-190^{\circ} \\
\text { to } \\
+20^{\circ} \mathrm{C}\end{array}$ & $\begin{array}{c}+20^{\circ} \\
\text { to } \\
60^{\circ} \mathrm{C}\end{array}$ & $\begin{array}{l}20^{\circ} \text { to } \\
100^{\circ} \mathrm{C}\end{array}$ & $\begin{array}{l}20^{\circ} \text { to } \\
200^{\circ} \mathrm{C}\end{array}$ & $\begin{array}{l}20^{\circ} \text { to } \\
300^{\circ} \mathrm{C}\end{array}$ & $\begin{array}{l}20^{\circ} \text { to } \\
400^{\circ} \mathrm{C}\end{array}$ & $\begin{array}{l}20^{\circ} \text { to } \\
500^{\circ} \mathrm{C}\end{array}$ & $\begin{array}{l}20^{\circ} \text { to } \\
600^{\circ} \mathrm{C}\end{array}$ & $\begin{array}{l}20^{\circ} \text { to } \\
700^{\circ} \mathrm{C}\end{array}$ \\
\hline $1641 B_{-. .}$ & $\left\{\begin{array}{l}1, \text { heating } \\
1, \text { cooling }\end{array}\right.$ & $\begin{array}{r}\times 10^{-6} \\
5.5 \\
5.5\end{array}$ & $\begin{array}{c}\times 10^{-6} \\
8.3 \\
8.3\end{array}$ & $\begin{array}{r}\times 10^{-6} \\
6.8 \\
6.8\end{array}$ & $\times 10^{-6}$ & $\begin{array}{c}\times 10^{-6} \\
\end{array}$ & $\times 10^{-6}$ & $\begin{array}{c}\times 10^{-6} \\
\end{array}$ & $\times 10^{-6}$ & $\times 10^{-6}$ & $\begin{array}{c}\times 10^{-6} \\
\end{array}$ & $\times 10^{-6}$ \\
\hline $1641 \mathrm{~A} \ldots$ & $\left\{\begin{array}{l}1, \text { heating- } \\
1 \text {, cooling } \\
2 \text {, heating. } \\
2 \text {, cooling- } \\
3 \text {, heating- } \\
3 \text {, cooling- }\end{array}\right.$ & 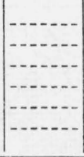 & \begin{tabular}{|c|}
$--\cdot-$ \\
\\
\hdashline
\end{tabular} & 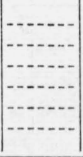 & 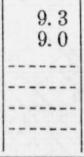 & $\begin{array}{l}8.9 \\
9.2 \\
8.8 \\
9.2 \\
9.0 \\
9.4\end{array}$ & $\begin{array}{l}9.5 \\
9.7 \\
9.1 \\
9.5 \\
9.4 \\
9.8\end{array}$ & $\begin{array}{l}9.4 \\
9.8 \\
9.5 \\
9.7 \\
9.7 \\
9.9\end{array}$ & \begin{tabular}{c}
9.8 \\
\hdashline 9.7 \\
\hdashline 9.7 \\
\hdashline-0
\end{tabular} & \begin{tabular}{r}
10.0 \\
10.1 \\
10.0 \\
\hdashline..-- \\
$-\cdots$
\end{tabular} & $\begin{array}{c}0.4 \\
10.1 \\
\end{array}$ & $\begin{array}{l}10.7 \\
10.4 \\
10.5 \\
10.5\end{array}$ \\
\hline
\end{tabular}

Figure 3 indicates the relation between the coefficient of expansion or rate of expansion, of titanium and temperature between $-150^{\circ}$ and $+650^{\circ} \mathrm{C}$. The curve is concave toward the temperature axis between $-150^{\circ}$ and about $+50^{\circ} \mathrm{C}$, and is linear at higher temperatures. The coefficient of expansion of titanium, $8.5 \times 10^{-6} /{ }^{\circ} \mathrm{C}$ at room temperature, is appreciably higher than the value $7.14 \times 10^{-6}$ published in the Metals Handbook referred to previously.

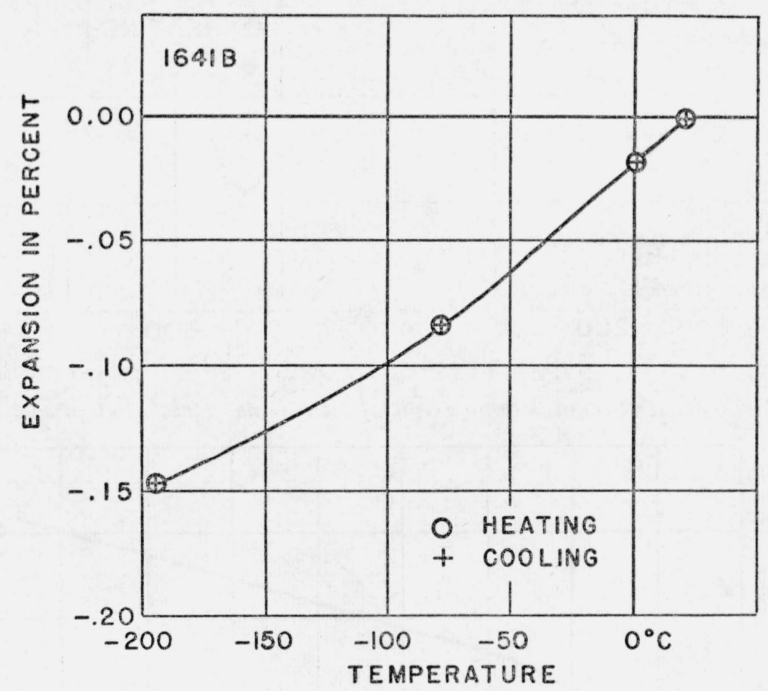

Figure 1.-Linear thermal contraction of titanium on cooling below room temperature, and expansion on subsequent heating from $-190^{\circ} \mathrm{C}$ to room temperature.

The data on the linear thermal expansion of titanium show no evidence of polymorphic transformations between $-190^{\circ}$ and $+700^{\circ}$ C. Koenigsberger and Schilling ${ }^{6}$ investigated the electric resistance of titanium between $-190^{\circ}$ and $+800^{\circ} \mathrm{C}$ and reported polymorphic

\footnotetext{
${ }^{\circ} \mathrm{J}$. Koenigsberger and K. Schilling, Über Elektrizitätsleitung in festen Elementen und Verbinungen. I. Minima des Widerstandes, Prüfung auf Elektronenleitung, Anwendung der Dissoziationsformeln, Ann. Physik 32, $179(1910)$.

$503599-43-2$
} 
104 Journal of Research of the National Bureau of Standards

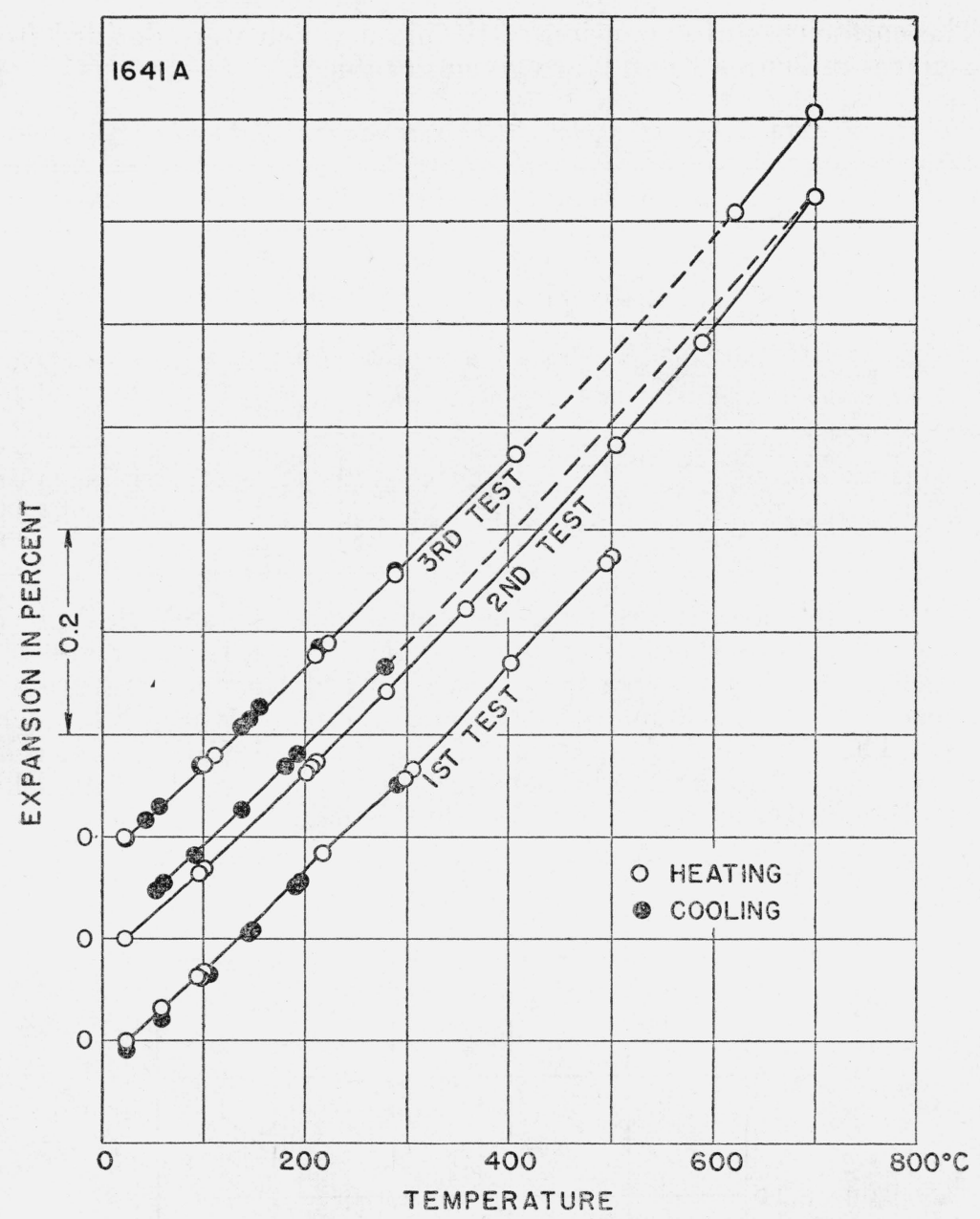

Figure 2.-Linear thermal expansion of titanium at elevated iemperatures.

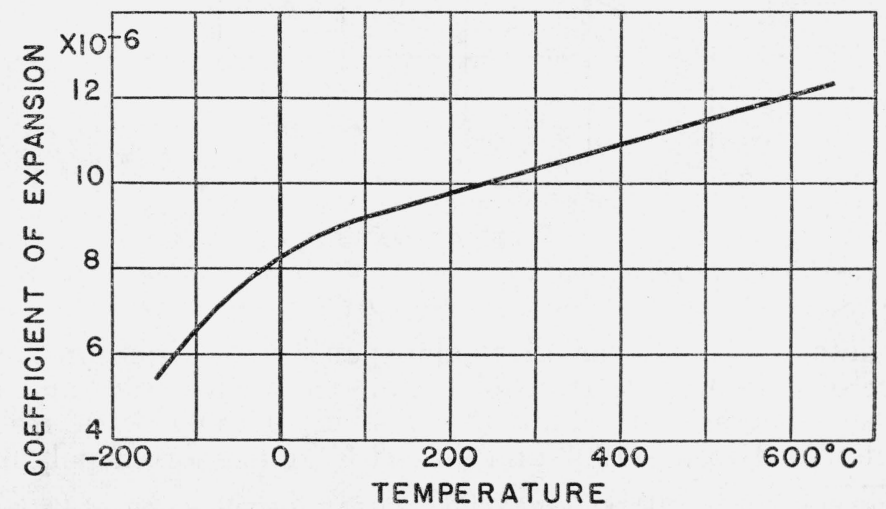

FIGURE 3.-Relation between coefficient of expansion of titanium and temperature. 
transformations at about $310^{\circ}$ and $590^{\circ} \mathrm{C}$. Schulze ${ }^{7}$ also determined the electric resistance of titanium, but he found no evidence of transformations between $0^{\circ}$ and $1,200^{\circ} \mathrm{C}$.

In order to secure more evidence on the presence or absence of polymorphic transformations in titanium, a small specimen cut from the plate of titanium was heated to $720^{\circ} \mathrm{C}$ and then cooled to room temperature. ${ }^{8}$ The time-temperature curves show no evidence of transformations, either on heating or cooling of the specimen.

Washington, September 5, 1942.

7 A. Schulze, Umwandlungserscheinungen an sogenannten Halbleitern, Z. Metalkunde 23, 261 (1931) or Über die Umwandlungen von Metallen, Z. Vereines deut. Ing. 76, 108 (1932).

- By S. J. Rosenberg, of the National Bureau of Standards. 